УДК $378.1: 371.134$

DOI:

Аліна Теплицька, кандидат педагогічних наук, дочент кафедри природничо-наукової підготовки Міжнародного гуманітарно-педагогічного інституту “Бейт-Хана”, м. Дніпро

\title{
НАУКОВО-ТЕОРЕТИЧНИЙ АСПЕКТ ПРОФЕСІЙНОЇ КОМПЕТЕНТНОСТІ: УКРАЇНСЬКА НАУКОВА ШКОЛА
}

У статті розглядається та уточнюється сутність понять “професійні компетенції, "професійна компетентність”, “кваліфікаційна характеристика”, “професійна готовність”, “професіоналізм”, які викладені у наукових прачях видатних українських вчених, які вивчають проблеми компетентнісного підходу у освіті. Вивчаються різноманітні джерела педагогічної літератури. Здійснено аналіз теоретичних досліджень видатних украӥнських науковців та висвітлено деякі поняття, які розкривають сутність професійної компетениії. Встановлено доизільність дослідження понять "професійна характеристика", “професійна готовність" та "професіоналізм” для подальщого розвитку професійної компетентності педагогів.

Ключові слова: освіта; компетениії; професіональна компетенція; професіоналізм; кваліфікаиійна характеристика; професійна готовність.

Puc. 1. Лim. 12.

\author{
Alina Teplytska, Ph.D.(Pedagogy), Associate Professor \\ of the Natural Science Departament \\ Humanities and Pedagogical Institute "Beyt-Khana”, Dnipro
}

\section{SCIENTIFIC AND THEORETICALASPECTS OF PROFESSIONAL COMPETENCE: UKRAINIAN SCHOOL OF SCIENCE}

The article outlines the meaning of terms "professional competencies", "professional competency", "qualification profile", "professional readiness", "professionality", that are defined in the scientific works of many Ukrainian scientists that study the problems of competency based approach in education. These terms are clarified more in this article. The different sources of pedagogical literature had been explored. The analysis of the theoretical researches of outstanding Ukrainian scientists was made and special attention was given to the disclosure of certain concepts that reveal the matter of such an important term in pedagogy as a professional competence. Among other things, qualification characteristics of professions of pedagogical and scientific-pedagogical workers of educational institutions that were published by the Ministry of Education have been studied; also the encyclopaedical teacher's dictionary was studied and various levels of qualification were revealed, including simple absorption of knowledge and skills; range and fullness of knowledge and skills; ability to perform special tasks; the ability to rationally organize and plan their work; the ability to use knowledge in abnormal situation. After summarizing the studied material, the author's definition of job description of teacher was given.

The article deals with the contradictions between the qualities of an individual that consist in the characteristic of a modern teacher and objective requirements, norms, standards, values of activities of the profession.

The definitions of Ukrainian scientists regarding readiness for professional activity were investigated, and the author's definition, based on the dynamic development of the Ukrainian system of pedagogical education was given.

Some stages of the process of knowledge acquisition were identified, including the psychological preparation, submission of new information, a stage of independent application of the acquired knowledge.

Requirements of modern regular school were defined from pedagogical educational institutions to the teacher: what kind of skills should he have, how he can critically evaluate the pedagogical problems and find the way to solve them, how he can change his activities taking into account the requirements of pedagogical situation, how to make a real and reasonable choice of elements of the content of education and methods of teaching during lesson planning; what he should know and what kind of skills should he have.

The definition of professional excellence was observed and its core factors are defined.

The necessity of studying the terms "qualification profile", "professional readiness", "professionality" was established for further development of professional competency of teachers in the world of global transformations that are taking place at the present stage of social and economic Ukrainian development in all fields of life sustaining activity of society.

The conclusion is made about the professional competence of the specialist as an integrated system quality, characterizing the potential capabilities of the individual (knowledge, skills, and experience), the level and dynamics 
of their expansion in the current field, the readiness to develop the professional actions and implement them into practice.

Keywords: an education; the professional competence; competences; the qualification characteristic; professional readiness; professionalism.

П остановка проблеми. Глобальні перетворення, що відбуваються на сучасному етапі соціальноекономічного розвитку України в усіх сферах життєдіяльності суспільства, обумовили необхідність оновлення і усієї системи освіти у цілому. Зрозуміло, що на сьогоднішній день якість освіти не може визначатися такими ж знаннями, вміннями та навичками, що використовувались раніше. Необхідність підготовки випускників до успішного розвитку кар'єри в умовах стрімкого розвитку суспільства потребує перегляду відносин між вищою школою та сучасним ринком праці.

Прогресивне реформування і розвиток системи неперервної освіти в Україні, результати численних досліджень у проектуванні нових освітніх і педагогічних технологій, пов'язаних з проблемою формування й розвитку професіоналізму педагога, вимагають постійного вивчення, узагальнення й систематизації.

У зв'язку з чим, одною $з$ важливих, а також стратегічною задачею професійної освіти в умовах сучасності стає задача формування особистості фахівця з високим рівнем професійної компетентності, здатної адаптуватися до швидких змін в економіці та у соціальних умовах.

Аналіз актуальних досліджень. Сутність та значення компетентнісного підходу та професійної компетентності у сучасній освіті висвітлюються упрацях багатьох українських науковців: Н. Баловсяк, I. Беха, Н. Бібік, Д. Гришина, О. Дубасенюк, В. Крижко, О. Локшиної, В. Лугового, Т. Майборди, Н. Ничкало О. Овчарук, О. Пометун, О. Савченко, Л. Хоружої, Н. Чепелєвої, Т. Яценко та ін.

Але не зважаючи на велику кількість публікацій і досі існує потреба у систематизації та узагальненні усіх досліджень 3 метою удосконалення підходів стосовно професійної компетентності у сучасній системі вітчизняної освіти.

Мета статті. Проаналізувати та зробити спробу узагальнення підходів науковців України щодо трактування професійної компетентності у сучасній освіті.

Методи дослідження в науковій статті застосовуються переважно теоретичні: вивчення джерел, аналіз і синтез матеріалів теоретичних досліджень та узагальнення педагогічної літератури стосовно професійної компетентності вчителя.
Виклад основного матеріалу. Термін “професіоналізм" у сучасній педагогічній літературі застосовується для позначення великої кількості сукупності елементів, які відображають високо продуктивну професійну діяльність. Під професіоналізмом, як правило, розуміється володіння спеціалістом системою спеціальних знань, вмінь та навиків, які дозволяють вирішувати задачі, які постають перед цим спеціалістом, відповідно до найбільш поширених у світовій практиці, і у той самий час, обгрунтованими с точки зору ї ефективності, критеріями. Кожна конкретна професія, спеціальність пропонує свій набір компетенцій, відсутність яких унеможливлює адаптацію та успішне виконання професійної діяльності. Такі компетенції і називають професіональними або професійно значимими компетенціями.

При розгляді кожного компонента професійної компетентності увага акцентується на наступному: професійні якості особистості, які є основою професійної компетентності представлені наступними елементами діяльності: вміння аналізувати трудовий та технологічний процес; аналіз документації, завдань, безпомилковість завдань; безпомилковість виконання робіт трудового кодексу; створення професійно значущої інформації, яка стосувалась би стану об'єктів діяльності; прогнозування появи та розвитку нештатних ситуацій; забезпечення техніки безпеки; освоєння додаткових кваліфікацій; високий рівень культури і організації трудового процесу; виконання рекомендацій, норм і вимог, що стосуються фізіологічних, економічних, екологічних факторів та ін.; соціальнокомунікативні здібності, які пронизують колективний трудовий процес, проявляються у певних здібностях кожного учасника, таких як: здатність до співпраці в колективній діяльності; вміння ефективно працювати у парі та складі групи; здатність до адаптації до різних темпераментів і характерів (психологічна сумісність); здатність встановлювати контакти; щиру повагу до праці інших; толерантність; здатність вирішувати конфлікти, організовувати роботу групи і ін.; здатність до самоврядування вимагає таких індивідуальних здібностей, як: вміння міркувати й оцінювати; здатність проявляти ініціативу, приймати на себе відповідальність, керувати собою та іншими; здатність виявляти проблему, самостійно ставити 
завдання і вирішувати їх; вміння самостійно вчитися та навчати інших своєї професії; здатність критично аналізувати власну професійну діяльність і роботу інших, приймати раціональні рішення в критичній ситуації і ін.

У теорії педагогічної освіти поняття “професійна компетентність” позначає сукупність професійно обумовлених вимог до спеціаліста та використовується 3 такими термінами, як “кваліфікаційна характеристика”, “професійна готовність”, “професіоналізм” (рис. 1). забезпечують виконання професійної діяльності і відображають придатність спеціаліста до якогонебудь виду праці. Професійна кваліфікація виражається в розрядах. Розрізняють рівні кваліфікації: простого засвоєння знань і умінь; діапазон і широта знань і умінь; здатність виконувати спеціальні завдання; здатність раціонально організувати і спланувати свою роботу; здатність використовувати знання в нестандартній ситуації [2].

Дамо своє тлумачення кваліфікаційної

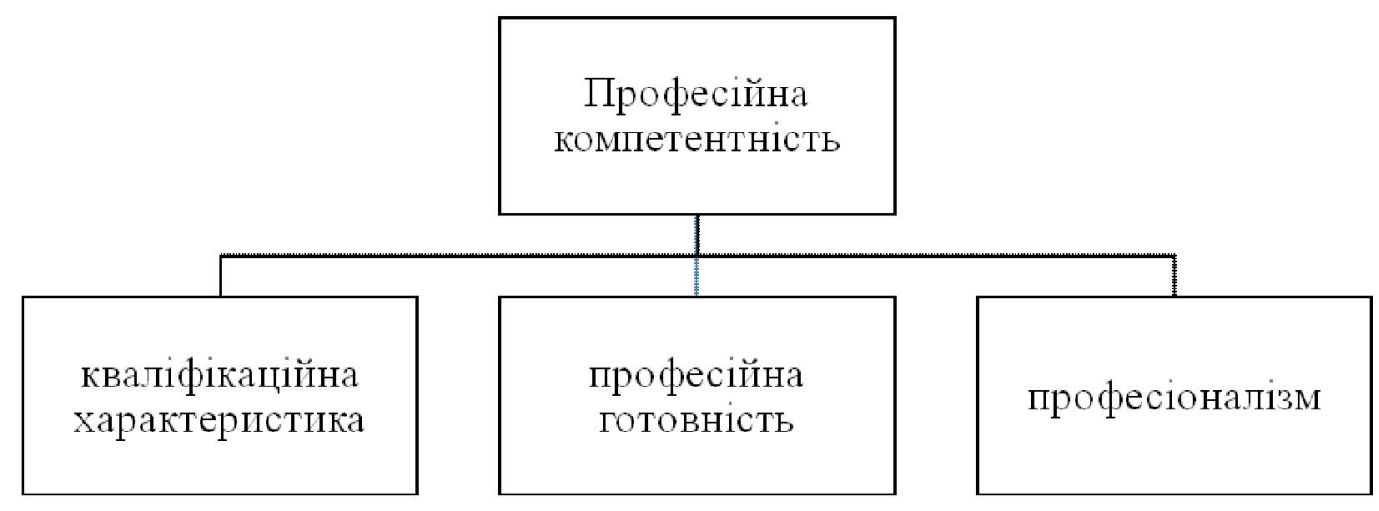

\section{Рис. 1. Структура поняття "професійна компетентність"}

Розглянемо у даній статті деякі визначення цих термінів.

Кваліфікаційна характеристика - це нормативний документ компетентного фахового органу, погоджений із замовником кадрів, у якому формулюються вимоги до професійних якостей, знань і умінь фахівця, що необхідні для виконання завдань професійної діяльності згідно з потребами ринку праці [6].

У словнику антикризового управління бачимо визначення поняття кваліфікаційна характеристика таке як короткий виклад основних завдань, навичок та вмінь, прав і обов'язків, що пред'являються до різних спеціальностей в організації [12].

С. Вишнякова у свому словнику визначає кваліфікаційну характеристику як Державний нормативний документ, що визначає місце фахівця в народному господарстві країни, основні вимоги до його суспільно-політичних, світоглядних і професійних якостей, до знань і вмінь, необхідних для успішного виконання трудових і громадських обов' язків в умовах сучасного виробництва [4].

Також важливим $\epsilon$ визначення яке дається у енциклопедичному словникупедагога: професійна кваліфікація - це певна ступінь професійної підготовленості працівника до виконання того чи іншого виду праці певної якості і складності; це система конкретних знань, навичок, умінь, що характеристики педагога. Кваліфікаційна характеристика педагога - складова професійної компетентності педагога, яка визначає ступінь професійної підготовленості педагога, рівень знань, навичок і умінь, здатність до саморозвитку та самовдосконалення які у сукупності забезпечують виконання професійної педагогічної діяльності.

Міністерством освіти оприлюднені кваліфікаційні характеристики професій (посад) педагогічних і науково-педагогічних працівників навчальних закладів. Про це йдеться у відповідному наказі освітнього відомства. Цим документом визначено, що кваліфікаційні характеристики посад педагогічних та науково-педагогічних працівників навчальних закладів та установ освіти повинні сприяти добору і розстановки кадрів, підвищення їх ділової кваліфікації, раціонального розподілу праці, створення дієвого механізму розмежування функцій, повноважень і відповідальності між працівниками [10].

Таким чином, підготовка майбутнього викладача у закладі вищої освіти, з огляду на кваліфікаційні характеристики професії, вимагає удосконалення змісту його теоретико-практичної підготовки 3 урахуванням визначених вимог та потреб суспільного розвитку, міжпредметної інтеграції та зв'язку із практичною діяльністю [9]. 
Професійна готовність студента особистісна якість, яка проявляється в позитивній самооцінці себе як суб' єкта майбутньої професійної діяльності та прагненні займатися нею після закінчення ЗВО. Вона допомагає молодому фахівцю успішно реалізовувати професійні функції, правильно використовувати набуті знання і досвід, зберігати самоконтроль i долати непередбачені перешкоди. Професійна готовність - вирішальна умова швидкої адаптації випускника до умов праці, подальшого його професійного вдосконалення і підвищення кваліфікації [11].

Професійно-особистісний розвиток педагога детермінується суперечністю між якостями особистості, що склалися у нього, і об'єктивними вимогами, нормами, стандартами, цінностями професійної діяльності. Метою і результатом професійно особистісного розвитку є такі новоутворення, як професійна готовність, готовність до діяльності і готовність до саморозвитку, професійна свідомість і самосвідомість, формує мотивацію фахівця [7].

Професійна готовність $є$ закономірним результатом спеціальної підготовки, самовизначення, освіти й самоосвіти, виховання й самовиховання. Це - психічний, активно-дієвий стан особистості, складна ii якість, система інтегрованих властивостей. Така готовність регулює діяльність, забезпечує ії ефективність [1].

На думку О. Комар “готовність до професійної діяльності" - це інтегрована якість особистості для якої характерні постійне прагнення самовдосконалення, збагачення особистісного педагогічного досвіду, ознайомлення і аналіз нових педагогічних концепцій навчання і виховання учнів, самостійно апробувати і застосовувати одержану інформацію у своїй професійній діяльності [8].

Враховуючи вищезазначені визначення професійної готовності можемо зазначити що сучасний педагог повинен вміти застосовувати на практиці знання та вміння, володіти різноманітними підходами у педагогіці, вміти аналізувати нові інноваційні педагогічні концепції.

Професіоналізм педагога формується під впливом багатьох факторів. Сучасний період модернізаційних змін у системі сучасної освіти пов'язаний $з$ реалізацією технологічного i компетентнісного підходів до процесу навчання. У педагогічних дослідженнях умовно виділяють декілька етапів процесу засвоєння знань: психологічна підготовка, подача нової інформації, етап самостійного застосування отриманих знань.

Сучасний педагог повинен стати носієм цінностей освіти, має бути підготовленим до вибору та реалізації різних концепцій в умовах варіативної багаторівневої освіти, до постійної самоосвіти, самовдосконалення, саморозвитку, підвищення рівня професіоналізму. Крім того, сучасна загальноосвітня школа чекає від педагогічних навчальних закладів такого вчителя, який володіє уміннями критично оцінювати педагогічні проблеми і знаходити шляхи їх вирішення, адекватно змінювати свою діяльність з урахуванням вимог педагогічної ситуації, робити усвідомлений та обгрунтований вибір елементів змісту освіти й методів навчання при проектуванні уроку. Він повинен знати про історичні витоки проблеми педагогічного професіоналізму та сучасні підходи до розуміння його сутності; зміст основних понять теорії і технології педагогічної праці та їх співвідношення; сучасні моделі педагогічного професіоналізму, його сутнісні ознаки, зміст, структуру; закономірності й особливості професіогенезу майбутнього вчителя, його етапи, рівні, ступені; наукові уявлення про відбір змісту, методів і форм навчання, що висувають із загальної методології педагогічного процесу; психолого-педагогічні засади змісту й організації процесу навчання; можливості та способи використання сучасних інформаційних, комунікаційних та мультимедійних технологій у процесі навчання; про сучасні напрями освіти, що пов'язані з їі гуманізацією та диференціацією, реалізацією розвиваючої функції навчання в контексті компетентнісного та технологічного підходів до проектування навчального процесу.

Отже, професіоналізм освітянина як соціальнопедагогічне явище, характеризує суспільносприйнятливу якість педагогічної праці на необхідних і достатніх рівнях, що забезпечує стабільне функціонування педагогічних систем. Відображаючи норми і цінності культури професійно-педагогічного середовища, такі характеристики розкриваються в соціальногромадському, науково-пізнавальному, організаційноуправлінському, предметно-методичному ракурсах та фіксуються у програмних і нормативноінструктивних документах, кваліфікаційних характеристиках, навчальних планах та програмах, методичномузабезпеченні підготовки та перепідготовки різних категорій педагогічних працівників [5].

Варто зауважити, що високий рівень професіоналізму, самоорганізації професійної діяльності вихователя, який забезпечує саморозвиток особистості дитини, забезпечується його педагогічною майстерністю. Педагогічна майстерність являє собою комплекс властивостей особистості. Системотворчим фактором 
педагогічної майстерності є гуманістична спрямованість на особистість дитини, утвердження словом і працею найвищих духовних цінностей, моральних норм поведінки і стосунків. Це вияв професійної ідеології педагога, його ціннісного ставлення до педагогічної дійсності, їі мети, змісту, засобів, суб'єктів [3].

В умовах сучасності, крім професіоналізму, під яким розуміється володіння певними технологіями, потрібно щось таке, що може забезпечити конкурентоспроможність фахівця на ринку праці. На сьогоднішній день умови життя вимагають від фахівця наявності в його “портфоліо” ще цілого ряду елементів, що мають надпрофесійний характер. До них відносяться такі якості особистості, як самостійність, здатність до самозайнятості, творчий підхід до будь-якої справи, вміння доводити його до кінця; постійне навчання та оновлення своїх знань; гнучкість мислення; наявність абстрактного, системного і економічного мислення; вміння вести діалог, товариськість, сформованість моральної позиції.

Висновки. Таким чином, аналіз літератури 3 досліджуваної нами проблеми, дозволяє зробити висновок про те, що професійна компетентність фахівця є інтегрованою системною якістю, що характеризує потенційні можливості особистості (знання, вміння, досвід), рівень і динаміку їх розгортання в актуальній області, готовність розробляти професійні дії і реалізовувати їх на практиці. Професійна компетентність тісно пов'язана з вмістом підготовки фахівця, будучи його складовою частиною.

\section{ЛІТЕРАТУРА}

1. Бартків О. Готовність педагога до інноваційної діяльності / О.Бартків // Проблеми підготовки сучасного вчителя. 2010. - № 1.C.52-58.

2. Безрукова В.С. Основы духовной культуры. Энциклопедический словарь педагога. Екатеринбург: ГОУ ВПО УГТУ-УПИ, 2000. $937 \mathrm{c}$.

3. Біла I. М. Професіоналізм педагога як передумова становлення творчої особистості дитини / І.М. Біла // Педагогічна Спадщина В. О. Сухомлинського у діалозі із сучасністю. - Луцьк., 2014. - С.38-42.

4. Вишнякова С.M. Профессиональное образование Словарь. Ключевые понятия, термины, актуальная лексика. - Москва: НМЦ СПО, 1999. - 538 с.

5. Гузій Н.В. Педагогічний професіоналізм як наукова категорія / Н.В.Гузій // Педагогічна творчість, майстерність, професіоналізм у системі підготовки освітянських кадрів: здобутки, пошуки, перспективи: монографія / керівн. авт. кол. Н.В.Гузій; Мін-во освіти і науки України, Нац. пед. ун-т імені М. П. Драгоманова. - К.: Вид-во НПУ імені М. П. Драгоманова, 2015. - 432 с. - С.122123.

6. Кваліфікаційна характеристика: [Електронний ресурс] // Вільна енциклопедія "Вікіпедія" - Режим доступу: https://uk.wikipedia.org/wiki/Кваліфікаційна характеристика

7. Кобыльник Л.Н. Профессиональная компетентность педагога высшей школы / Л.Н. Кобыльник // Журнал “Современная наука: Актуальные проблемы теории и практики. Серия: “Гуманитарные науки”. - Москва, 2014. - № 3-4. - C. 61-63.

8. Комар О.А. Підготовка майбутніх учителів початкової школи до застосування інтерактивних технологій. Теоретико-методологічні аспекти: монографія / О.А. Комар. - Умань: РВЦ “Софія”, 2008. - $332 \mathrm{c}$.

9. Мирончук Н.М. Кваліфікаційні вимоги до викладачів вищих навчальних закладів як основа змісту освітньо-професійних програм підготовки фахівців / Н.М. Мирончук // Проблеми освіти: Збірник наукових праць. - Вінниця; Київ, 2015. Вип. 82. - С. 172-176.

10. Наказ МОН № 665 від 01 червня 2013 року “Про затвердження кваліфікаційних характеристик професій (посад) педагогічних та науковопедагогічних працівників навчальних закладів" [Електронний ресурс]. - Режим доступу: http:// osvita.ua/legislation/other/37302/

11. Приходько Ю.О. Психологічний словникдовідник: навчальний посібник / Ю. О. Приходько, В. І. Юрченко. - Київ: “Каравела”, 2012. - 328 с.

12. Словарь терминов антикризисного управления. - 2000. [Електронний ресурс]. Режим доступу: http://economics.niv.ru/doc/ dictionary/crisis-management/fc/slovar-202.htm\#zag$\underline{170}$

\section{REFERENCES}

1. Bartkiv, O. (2010). Hotovnist pedahoha do innovatsiinoi diialnosti [Teacher's readiness to innovative professional activity]. Problems of modern teacher's training. No. 1, pp. 52-58. [in Ukrainian].

2. Bezrukova, V.S. (2000). Osnovy dukhovnoy kultury. Entsiklopedicheskiy slovar pedagoga. [Fundamentals of spiritual culture. Collegiate Dictionary of Teacher]. Ekaterinburg: GOU VPO UGTU-UPI Publ., 937 p. [in Russian].

3. Bila, I. M. (2014). Profesionalizm pedahoha yak peredumova stanovlennia tvorchoi osobystosti 
dytyny [The professionalism of the teacher as a prerequisite for the formation of the child's creative personality]. V. O. Sukhomlynsky's Pedagogical Legacy in Dialogue with Modernity. Lutsk, pp. 3842. [in Ukrainian].

4. Vishnyakova, S.M. (1999). Professionalnoe obrazovanie Slovar. Klyuchevye ponyatiya, terminy, aktualnaya leksika. [Vocational Education Vocabulary. Key terms, terms, current vocabulary]. Moscow: NMTs SPO Publ., 538 p. [in Russian].

5. Huzii, N.V. (2015). Pedahohichnyi profesionalizm yak naukova katehoriia [Pedagogical professionalism as a scientific category of educational personnel:]. Pedahohichna tvorchist, maisternist, profesionalizm u systemi pidhotovky osvitianskykh kadriv: zdobutky, poshuky, perspektyvy. Monohrafiia [The pedagogical creativity, skill, and professionalism in the system of training of educational personnel: the achievements, searches, and perspectives: monograph]. Ministry of Education and Science of Ukraine, National Pedagogical Dragomanov University. Kyiv: NPU imeni M. P. Drahomanov Publ., 432 p., pp.122-123. [in Ukrainian].

6. Kvalifikatsiina kharakterystyka: Vilna entsyklopediia "Vikipediia" [Qualifying characteristic: Free Encyclopedia "Wikipedia"]. Available at: https:/ /uk.wikipedia.org/wiki/Кваліфікаційна _характеристика. [in Ukrainian].

7. Kobylnik, L. N. (2014). Professionalnaya kompetentnost pedagoga vysshey shkoly [The professional competence of the teacher of higher education]. Journal "Modern Science: Actual Problems of Theory and Practice”. Series:
“Humanities”. Moscow. No. 3-4, pp. 61-63. [in Russian].

8. Komar, O. A. (2008). Pidhotovka maibutnikh uchyteliv pochatkovoi shkoly do zastosuvannia interaktyvnykh tekhnolohii [Training of future primary school teachers to use interactive technologies]. Uman: RVTs "Sofiia" Publ., 332 p. [in Ukrainian].

9. Myronchuk, N.M. (2015). Kvalifikatsiini vymohy do vykladachiv vyshchykh navchalnykh zakladiv yak osnova zmistu osvitno-profesiinykh prohram pidhotovky fakhivtsiv [Qualification requirements for teachers of higher educational institutions as the basis of the content of educational professional programs of training specialists]. Problems of education: Collection of scientific works. Vinnitsa; Kyiv, vol. 82. pp. 172-176. [in Ukrainian].

10. Nakaz MON № 665 vid 01 chervnia 2013 roku "Pro zatverdzhennia kvalifikatsiinykh kharakterystyk profesii (posad) pedahohichnykh ta naukovopedahohichnykh pratsivnykiv navchalnykh zakladiv". Available at: http://osvita.ua/legislation/other/37302. [in Ukrainian].

11. Prykhodko, Yu. O. \& Yurchenko, V. I. (2012). Psykholohichnyi slovnyk-dovidnyk: navchalnyi posibnyk [Psychological Dictionary-Guide: Tutorial]. Kyiv: "Karavela" Publ., 328 p. [in Ukrainian].

12. Slovar terminov antikrizisnogo upravleniya (2000). [Dictionary of terms of anti-crisis management]. Available at: http://economics.niv.ru/ doc/dictionary/crisis-management/fc/slovar202.htm\#zag-170. [in Russian].

Стаття надійшла до редакції 06.09.2018

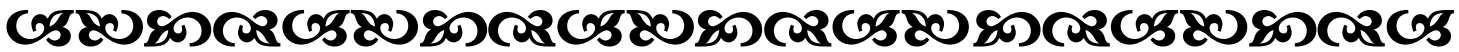

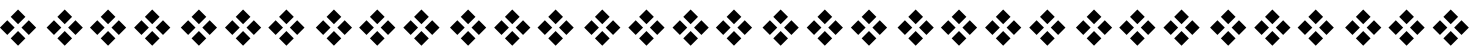

"Хочеш бути розумним, навчися розумно питати, уважно слухати, споқійно відповідати і переставати говорити, қоли нічого більше сқазати".

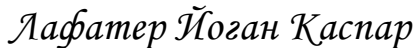
швейцарський білософ

"Найбільша і найважливіша частина виховання қожного- це те, що ми даруємо самі coбi”.

Едвард Тіббон

британсьжий історик

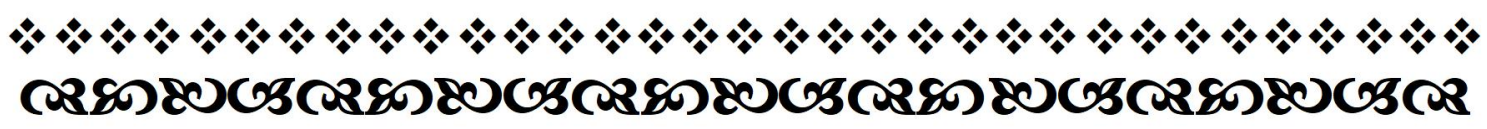

Молодь і ринок №10 (165), 2018 